dependent structures and also served as a barrier against southern marauders. Further excavation may show whether this view is to be regarded as final.

\section{Toxicology of Narcotic Drugs}

IN his presidential address before the Society of Public Analysts delivered on March 4, Dr. G. Roche Lynch discussed "The Toxicology of the Narcotic Drugs", embodying observations regarding the barbiturates, thio-barbiturates, straight-chain ureides and morphine, based on his own record of cases. He pointed out that the barbiturates, of which seventeen are now on the market, can be divided into two main groups, one of which produces light narcosis of long duration and the other deep narcosis of shorter duration. The individual barbiturates differ greatly in the rate at which they are destroyed in the body ; some are destroyed so rapidly that it is rarely possible to recover more than minute quantities of them from urine or tissues. The extent of their use is illustrated by the fact that 18 million tablets of one of them, and that not the most common, are produced annually. The habit of taking them at night regularly is widespread, especially among women; but in keeping them within reach as a means of inducing sleep there is a danger that, after one or two tablets have been taken, a state of 'automatism' might supervene, in which a person, more or less unconsciously, might take a further number, with serious results. For purposes of treatment, the analyst should be able, by examination of urine, to ascertain within a quarter of an hour whether or not a barbiturate had been taken; but for purposes of evidence in court a complete identification with melting point determination is desirable.

\section{Broadcasting Television}

Is a discussion in the House of Commons on March 11 of the supplementary estimate for $£ 360,000$ for the B.B.C., Major Tryon made some very satisfactory remarks. He pointed out that in this year's report there were two entirely new features. First there was the expansion of television which accounted for an additional $£ 295,000$, and also about $£ 15,000$ proposed for broadcasting news in foreign languages. The latter sum was not included in the original estimate as it was not a part of the policy of the Government. He said that Great Britain was the first country in the world to have a public television service. It had been found by the Television Advisory Committee that further experiments must be made before new recommendations could be accepted for extension. That was a scientific inquiry, and he was sure that the House would like to pay tribute to the men of science who had made this wonderful discovery, and to the B.B.C. and its engineers for bringing it into working order. He also expressed the gratitude of the Government to the Television Advisory Committee, under the chairmanship of Lord Selsdon, who had been given great help in scientific matters by Sir Frank Smith. The additional sum required for television was provided simply. In the future 8 per cent of the licence revenue should go to the B.B.C. to help with the additional work. Television had only lately been started and the cost had been very heavy. If the service was to be efficient there must be a greater accommodation of studios, etc. The technical standards of television had been stabilized for three years, and that gave security to producers of sets and encouraged them to make more sets and more cheaply. This grant would foster the growth and development of an infant industry in which we were at present leading the world.

\section{The British Broadcasting Corporation}

THE eleventh annual report of the British Broadcasting Corporation, which covers the year ended December 31, 1937, refers to the completion of the first year of operation of the London Television Station, and the year's experience is regarded as having justified the confidence in the future of television which led to its establishment. Financial uncertainty which had complicated further plans was relieved towards the end of the year by the Treasury's acceptance of the view that the costs involved should be met by a grant from the balance of net licence revenue retained by the Treasury. The adoption of the Marconi-E.M.I. transmitting standards as a single system in February made it possible to widen the scope of television programmes during the year, notably in outside broadcasts. Reference is also made in the report to the work of the Talks Advisory Committee, to attempts to promote closer contact with listeners and various experiments in technique. The Engineering Section of the report refers to developments in Empire service and to the obstacle which lack of sufficient wave-lengths continues to present to the planning of extensions to the home service. Further progress in experimental studio design has been made, and improved methods were adopted in the acoustical treatment of studios under construction. The results of research on the performance of short-wave directional aerials were successfully applied in the design of the Empire station. The total income for the year amounted to $£ 3,356,074$, of which 85.67 per cent was derived from licences and 14.32 per cent from publications. Of this income, more than 51 per cent was expended on programmes and nearly 18 per cent of the remainder on engineering. $£ 200,000$ were transferred to capital account, an amount insufficient to cover the year's expenditure on fixed assets. The report stresses the impossibility of building up any reserve funds in liquid form, although this is most essential while income is still increasing.

\section{Promotion of International Co-operation}

THE annual Bulletin of League of Nations Teaching, just issued by the secretariat (No. 4, December 1937), deals with the teaching of the facts and principles of international co-operation, this subtitle indicating that its scope has been extended to cover a wider field than the activities of the League 